International Journal of STEM Education for Sustainability, Vol 2, No.1, 2022, pp. 78-93

e-ISSN 2798-5091. DOI. 10.53889/ijses.v2i1.29

\title{
The Effect of STREAM-Based Teaching Materials Using Smart Apps Creator 3 on Students' Scientific Literacy
}

\author{
Submitted 26 November 2021 Revised 16 December 2021 Accepted 19 December 2021 \\ Fenny Pebriani $^{\mathbf{1}, 2}$, Leny Heliawati ${ }^{*}$, Didit Ardianto $^{1}$ \\ ${ }^{1}$ Science Education Program, Graduate School, Universitas Pakuan, Bogor, Indonesia \\ ${ }^{2}$ MTs Al-Ma’tuq Putri, Sukabumi, Indonesia \\ Corresponding Email: *leny_heliawati@unpak.ac.id
}

\begin{abstract}
This study aimed to develop STREAM-based water teaching using Smart Apps Creator 3 on students' scientific literacy. The method carried out by Research and Development uses the 4D design (Define, Design, Develop and Disseminate). The research data were collected and analyzed in the form of quantitative descriptive from the students' pre-test and post-test results. This research used a Google form by distributing a questionnaire given to students with 56 respondents and 11 science teachers who had used STREAM-based water teaching materials using SAC 3. The results of the study, the average percentage of scientific literacy with N-Gain was $76 \%$ with a high category, which means that the application of learning materials based on STREAM using Smart Apps Creator 3 is proven to improve student learning. Conclusion in this study is STREAM-based teaching materials using SAC 3 are statistically proven to improve students' scientific literacy to water material in online learning during the current pandemic.
\end{abstract}

Keywords: Scientific Literacy, Online, Smart Apps Creator 3, STREAM

\section{INTRODUCTION}

The world is currently faced with multidimensional problems due to the outbreak of Covid-19. Almost all aspects of life in various fields have been affected, such as education, society, economy, and tourism. In the field of education globally, this tragedy has had an enormous impact, so that it presents its challenges for educational institutions (Ayuni et al., 2020; Bao, 2020; Dewi, 2020; Dhawan, 2020; Fitriyani et al., 2020; Hodges et al., 2020; Sadikin \& Hamidah, 2020; World Health Organization, 2020). Learning in schools during a pandemic must be conducted online. School managers, teachers, students, and parents must change their learning patterns to a distance or online digital learning system known as elearning. Almost all school activities in various countries are eliminated and diverted from their homes to continue the learning process. About 1.723 billion students have been affected due to school closures in response to the pandemic, which has caused the quality of learning in students to decline (Nasir, 2020; Sahu, 2020).

An internet network with accessibility, connectivity, flexibility, and ability in online learning to generate various types of learning interactions is digital technology learning that makes it easier for students and teachers even though they are in different places. To access information in online learning, supporting devices such as smartphones or android phones, laptops, computers, tablets, and iPhones are needed, which can be used anytime and anywhere 
so that teachers and students can interact (Bao, 2020; Dhawan, 2020; Hodges et al., 2020; Nasir, 2020). Changes in learning and teaching patterns today will not be separated from the teacher's role. Teachers' readiness and confidence are the primary keys to dealing with teaching and learning activities (Ayuni et al., 2020; Roza et al., 2019; Zubaidi, 2020) so that in any condition, teachers who have good readiness in learning will improve their quality. Besides, it will help improve students' learning outcomes.

The use of mobile technology in online learning in educational institutions is convenient to support, including distance learning goals. Thus teachers are required to follow the times in the digital era. ICT is an essential tool to integrate into the learning process to develop learning media and multimedia. Teachers can arrange materials to be taught to students using software assistance in a combination of various media into an interactive multimedia learning device. Innovations related to learning models are needed in the learning process to realize 21 st-century learning. One of the learning models for scientific literacy to students is the STREAM (Science, Technology, Religion, Engineering, Arts, Mathematics) approach development of STEM. Based on the research results of Aberilla et al. (2021), it is necessary to develop a STEM-based learning design, which must be emphasized in the science curriculum. STEM education is implemented as a learning strategy and approach, integrated with other learning models, used as learning, and developed into teaching materials, modules, and learning media to improve skills in the 21st century (Farwati et al., 2021).

Literacy is the basis for the students' skills to apply core skills in daily tasks to understand and apply knowledge to solve problems. Students who understand the relationship between science, technology, and society and can apply their knowledge to solve problems in real life are human beings who are knowledgeable in science and technology (Odegaard et al., 2015; Wang \& Zhao, 2016; Rokhmah et al., 2017; Suratno et al., 2020 ). Along with the development of the 21st-century skills learning era (Trilling \& Fadel, 2010), to prepare the current 21 st century generation to face a time when scientific literacy was chosen as the main goal of science education (Odegaard et al., 2015; Wang \& Zhao, 2016; Aprido B. Simamora et al., 2020). Thus, it is necessary to have a positive attitude towards science and scientific literacy skills to succeed in his life and career in the future.

The importance of scientific literacy in Indonesia is one of the issues that must be considered. Based on the PISA (Program for International Students Assessment), the scientific literacy skills of Indonesian students are generally at the lowest measurement stage, which is still below the average compared to the average international score. During 2000 2019 several studies have found that to achieve scientific literacy, learning in Indonesia, in 
International Journal of STEM Education for Sustainability, Vol 2, No.1, 2022, pp. 78-93 e-ISSN 2798-5091. DOI. 10.53889/ijses.v2i1.29

general, cannot guide students optimally. From the Organization for Economic Cooperation and Development (OECD), Indonesia in PISA was ranked 38th out of 41 countries with 393 in 2000. In 2003, it was ranked 38th out of 40 countries with 395, 50th from 57 countries with 393 in 20016, and 60th out of 65 countries with 383 in 2009. The worst was in 2012 when it was ranked 64th out of 65 countries with a current ranking of 383. 2015 was ranked 64th out of 72 participating countries, with a score of 403. Furthermore, in 2018 it was ranked 71 out of 78 countries with 382 (OECD, 2003; OECD, 2013; OECD \& ADB, 2015; OECD, 2016; OECD, 2017; OECD, 2019). Thus, based on the survey results, the value of scientific literacy skills of Indonesian students set by the OECD institution is still far below the value of international standards.

Based on the description above, students' lacks of scientific literacy science learning problems require alternative solutions. The use of learning models and media that can train students' scientific literacy is an alternative solution in learning. Based on several previous studies on STREAM Education, "STREAM-based learning can equip students' creativity in Traditional Biotechnology content" (Agustina et al., 2019). Use the Project-Based Learning model using the STREAM-based approach to increase students' interest, creativity, and social attitudes in learning (Azizah et al., 2020). Combining aspects of religion and art with a STEM education will become STREAM in the future (H Mubarok, N S Safitri, 2020) .This study aims to develop STREAM-based water teaching materials using android-based interactive multimedia to improve students' scientific literacy in online learning.

STREAM in research integrated into water teaching materials is in the form of indicators for the domains of Science, Technology, Religion, Engineering, Art, and Mathematics. Science in the concept is the mastery of the water cycle concept and water's role in life. Technology is developing a filtration technology product to produce clean water. Religion appears in the concept of water that can be used for ablution. Engineering is developed with an activity plan to solve dirty water that can produce clean water by designing a filtration device. Domain art appears in plants (flowers) stored in water that has been given red, yellow, and blue colors in each location. Mathematics is calculating the discharge of clean water produced in the filtration process. Smart Apps Creators 3 interactive multimedia used in this study is integrated into Android devices. The teaching material developed refers to students' problem-solving and religious attitudes in mastering the science learning process concept with water teaching materials. 
International Journal of STEM Education for Sustainability, Vol 2, No.1, 2022, pp. 78-93

e-ISSN 2798-5091. DOI. 10.53889/ijses.v2i1.29

\section{METHOD}

The research subjects were conducted on 56 students of one junior high school in Indonesia and 11 science teachers. The selection of students to be research subjects used purposive sampling, which refers to Arikunto (2017). The development in designing and making android-based water teaching materials in this study used the Research and Development (R \& D) method with a Four-D development design (4D) which consists of 4 stages; Define, Design, Develop, and Disseminate. This model has been widely used by several researchers, including Thiagarajan and Sivasailam (1974), Dewi et al. (2019), and Khasanah et al. (2020). The R and D stages with 4D designs were simplified to the third stage, and this was due to the COVID-19 pandemic.

The data were collected by measuring students' scientific literacy. The measurement of the problem-solving skills test given to students was in multiple-choice questions as many as 20 questions. Each question has a score of 5, so the maximum score is 100 . The test is carried out online using Google Form with Scientific literacy competencies that include: explaining scientific phenomena, evaluating and designing scientific investigations, interpreting data and evidence scientifically. This test was tested with the one-group pretest-posttest design technique, Fraenkel et al. (2012). The scheme is shown in Table 1.

Table 1. Scheme of The One Group Pretest-Posttest Design

\begin{tabular}{lll}
\hline Pretest & Treatment & Posttest \\
\hline $\mathrm{T}_{1}$ & $\mathrm{X}$ & $\mathrm{T}_{2}$ \\
\hline
\end{tabular}

Through this pretest-posttest, measurement of skills is carried out before and after treatment of students' scientific literacy. T1 as a pretest is carried out before students are given treatment, $\mathrm{X}$ as Treatment is given through STREAM-based water learning materials using $S A C 3$, and $\mathrm{T} 2$ as a posttest carried out after giving the sample treatment.

The residual value is normally distributed or not, then a normality test is carried out to find the significant value in the Asymp column. If the residual value is normally distributed, it can be done by using the paired sample t-test. However, if the residual value is not normally distributed, the mean significant difference test can be done with a non-parametric statistical test, the Wilcoxon test (George \& Mallery, 2018). The basis for making research decisions is if the Sig p-value $<0.05$, then there is a significant difference between the value of problemsolving skills in the pretest and posttest data; however, if the value is Sig. P>0.05, so there is no significant difference between the pretest and posttest data values. After the data was declared normally distributed, an $\mathrm{N}$-Gain test was conducted by dividing the reduction 
between the posttest and the pretest scores divided by the maximum scores minus the pretest scores.

The effectiveness of Android-based teaching materials was calculated based on the students' feedback. Data collection of scientific literacy is in the form of quantitative results from learning daily test scores. Data in values are then analyzed by determining N-Gain based on Hake's (1999) category, as shown in Table 2.

Table 2. N-Gain Interpretation

\begin{tabular}{ll}
\hline N-Gain $(\%)$ & Interpretation \\
\hline$(\mathrm{g}) \geq 70$ & High \\
$70>(\mathrm{g}) \geq 30$ & medium \\
$(\mathrm{g})<30$ & Low \\
\hline
\end{tabular}

The research steps were carried out in several stages: planning, implementation, and final. The planning stage conducts curriculum analysis, including analysis of core competencies, basic competencies, learning indicators, and learning objectives, and compiling completeness of learning instruments and research instruments. The implementation stage includes a pretest, the implementation of learning using Android and then a posttest to measure students' problem-solving skills. The final stage is data analysis, discussion, and drawing research conclusions.

\section{RESULTS AND DISCUSSIONS}

Researchers carried out this first product development step to analyze the needs of students for science learning. Analysis of student needs is carried out to determine the learning process that can develop STREAM-based water teaching materials using android so that students are more active and understand the required learning material. Needs analysis is based on developmental steps through observation when the science lesson is taking place and interviews with the teacher to obtain information about students' characteristics. The preliminary observations to find problems that exist during the science learning process have been described in the introduction. Interviews with teachers were conducted due to observations to find out more about the problems that occur during science learning, teacher understanding regarding the use of STREAM-based teaching materials using SAC 3 as a learning media, especially interactive multimedia using android.

Through observations and interviews conducted with teachers, the research results can conclude that the use of STREAM-based teaching materials using android as a learning medium, especially interactive multimedia using PowerPoint, is very important and needs to 
Figure 1. Results of Validation of Android-Based Teaching Materials by Experts and Teachers

Figure 1 shows the validity of the teaching materials by two experts (lecturers), achieving $100 \%$ on the material aspect, $100 \%$ on the presentation, and the language and readability aspects of $91.7 \%$. While the validation carried out by 11 teachers showed maximum results in the material aspect of $100 \%$, the presentation aspect was $100 \%$, while the language and readability aspects obtained a value of $96.9 \%$.

Religious experts also carry out validation to assess the use of verses from the Qur'an and hadith that are integrated with the topic of water. The criteria assessed include the verses of the Qur'an and the hadiths used in accordance with the subject matter, the references used to understand the meaning of the verses of the Qur'an or the hadiths can be accounted for, the meaning of the verses of the Qur'an or the quoted hadiths are explained in-depth, the number of verses of the Qur'an or hadith quoted is adequate, and the Verses of the Qur'an or hadith are quoted in their entirety. The results of expert validation show an average percentage score of 92\%, which shows the verses of the Qur'an and hadith used are in accordance with the material, their meaning is explained in-depth, the number of verses of the Qur'an or hadith quoted is adequate. Based on the validation results of religious experts, multimedia is suitable for use in the learning process. The results can be seen in Table 4.

Table 4. Results of STREAM-Based Teaching Material Validation by Religious Experts

\begin{tabular}{ccccc}
\hline No & Expert & Total score & Total Percentage (\%) & Criteria \\
\hline 1 & Religious expert & 23 & 92 & Worthy
\end{tabular}

Before being tested, a normality test was conducted to determine the significance level of the pretest-posttest, a paired sample t-test was performed. As a prerequisite for the descriptive statistical test, the data normality test was carried out using the KolmogorovSmirnov Test technique. The output of the normality test and t-test on students' scientific literacy is presented in Table 5.

Table 5. Statistical Test Results

\begin{tabular}{lll}
\hline Pretest Posttest Data & Score Sig. & \multicolumn{1}{c}{ Information } \\
\hline Normality test & 0,364 & Normal distribution \\
Test t test & 0,000 & very significant \\
\hline
\end{tabular}

Based on the output of SPSS data, the significance value of Asymp. Sig (2-tailed) is 0.364 , which is greater than 0.05 , so it can be concluded that the data is normally distributed. The significance test of the difference in pretest and posttest results with the paired sample ttest using SPSS Version 22 software showed 0.000 , which means very significant. It can be 
concluded that there is an average difference between pretest and posttest scientific literacy. Thus, it can be interpreted that the use of STREAM-based interactive SAC multimedia can improve students' scientific literacy.

The results of the study were in the form of data analysis, and there was an increase in the value of pretest to posttest after students did learning with the SAC 3 application to get an $\mathrm{N}-$ Gain of $76 \%$, with the average value increasing from 48.48 to 87.68 after learning using the SAC 3 application based on STREAM, as the table shows Table 6.Table 6. The results of the pre-posttest analysis of Student Science Literacy

\begin{tabular}{lll}
\hline Android Implementation Data & Pretest & Posttest \\
\hline The number of students & 56 & 56 \\
Lowest value & 40 & 75 \\
The highest score & 60 & 100 \\
Average score & 48,48 & 87,68 \\
\hline \% N-Gain & $76 \%$ (high) \\
\hline
\end{tabular}

Based on research carried out on 56 respondents of students on scientific literacy, it is obtained data that the post-test results show an increase in the average value compared to the pretest results. It is in Figure 2

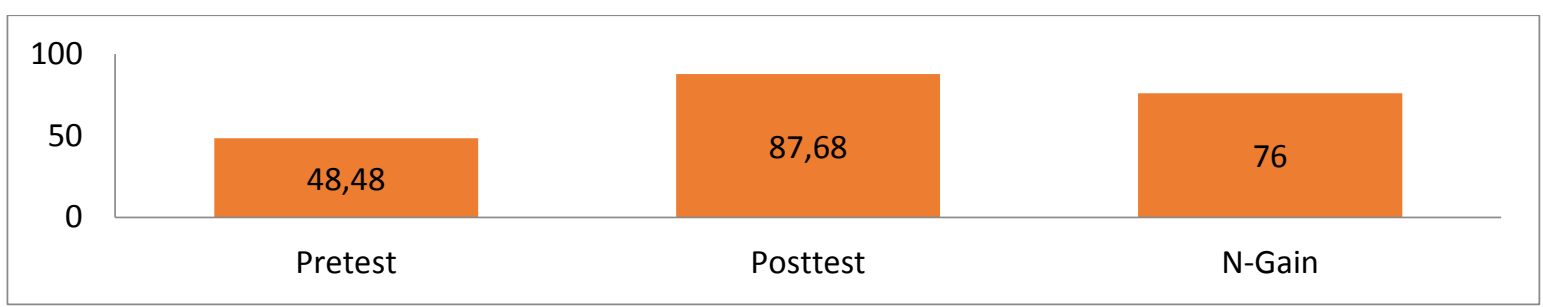

Figure 2. Comparison of the average value of pretest and posttest, N-Gain

Researchers carried out several steps for developing interactive multimedia products using STREAM-based SAC 3, which were designed as attractive as possible based on interactive multimedia aspects for students. The steps of product design development include, among others.

1. Description of each stage of development: Definition stage

Before the learning media is made, an initial stage must be done, namely the feasibility analysis of the SAC 3 program as a STREAM-based learning media application. Whether or not this media application is appropriate is collected from the responses of seventh-grade Madrasah Tsanawiyah students in Sukabumi, Indonesia. The results of the responses indicate that science teachers in MTs have used learning media. The media used are power points, projectors, videos, and books. Learning media that uses an application on Android has not been found. 


\section{Design or Design Stage}

The design of the SAC 3 application which is integrated with STREAM of water teaching materials for students of MTs class VII. The SAC 3 program was obtained from writer training at BPMTK (Multimedia and Computer Technology Training Center) Central Java. Before this application was made, pre-production and applied product framework were created. In the pre-production stage, a storyboard is created that contains the initial design of each view per slide that appears on the android screen. Not to forget the collection of assets from various sources to fulfill the material contained in the application, including image, video, audio, and text assets. This design stage is validated by media experts, namely media literate educational technology lecturers.

\section{Stage of development or Develop}

The STREAM-based SAC 3 application design results are compiled in full with various processes such as installing the SAC 3 program first, then making the opening or loading page, home, introduction, educational games, practice questions, developers or creators, and references. Each slide is filled with various assets that are adjusted to the sequence of learning materials based on STREAM water with indicators that students can describe the context of water in the STREAM aspect. The results of this media program design were validated by material and media experts from several competent universities, the validation results showed that this application-based media design was feasible and suitable for use in learning in class VII MTs. Although it is feasible, some things still need to be revised, such as the use of letters that have not been maximized, the selection of background colors, and the addition of instruments. STREAM-based SAC 3 interactive multimedia is also given to teachers to respond to the SAC 3 application. The response results show that this application is very good and needs to be applied to students, especially during this covid 19 pandemic as a learning medium.

\section{Design Results and Display}

At this stage, a design was produced that the researcher had done. The design results are explained as follows:

a. Loading page and application cover

The loading page and application cover are the opening pages of the STREAM-based SAC media. This loading and cover page is equipped with attractive images. It can be seen in Figure 3. 


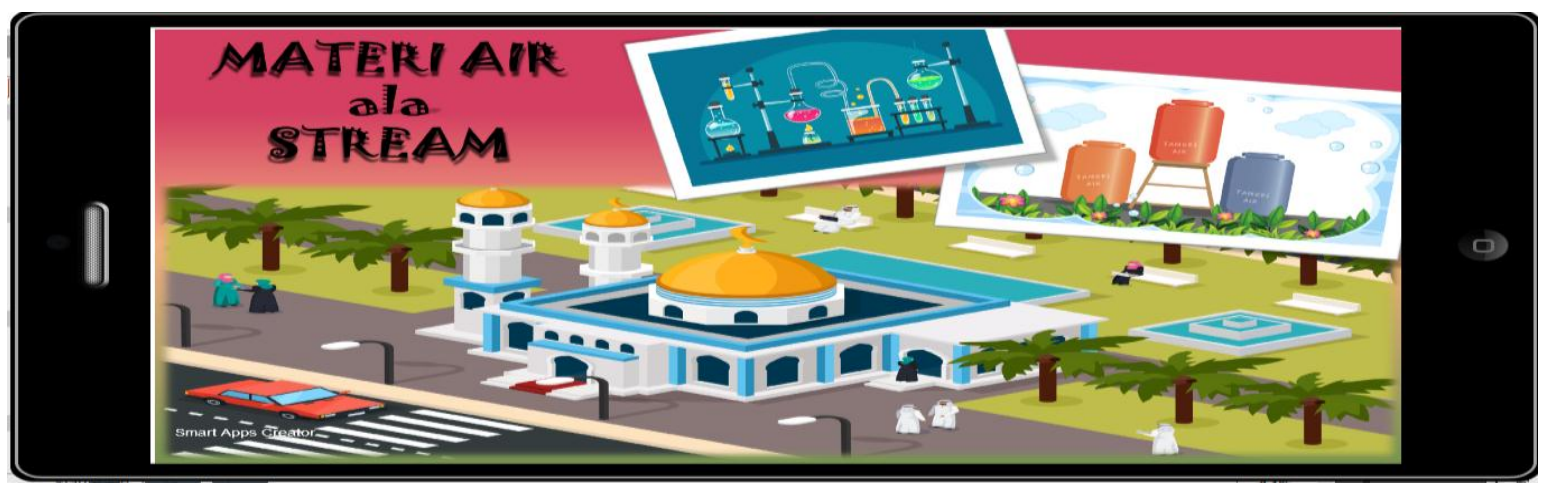

Figure 3. Loading page

a. Home or Home Menu,

The main menu page or home is a page that describes the initial appearance when entering the STREAM-based water material learning media. The main menu page is also equipped with various button features that will allow you to select the page you want to go. For example, if you want to enter the religious page, click the religious image circle on the menu page in the upper right corner. To enter the introduction page, click the box that says the introduction is in the upper left box of the menu page if you want to enter on another page. For example material, you can click the box labeled material in the middle box of the menu page. The instructions apply the same to entering another page by clicking the box that says the description on the page menu like a game education, practice questions, creators, and references which can be seen in Figure 4.

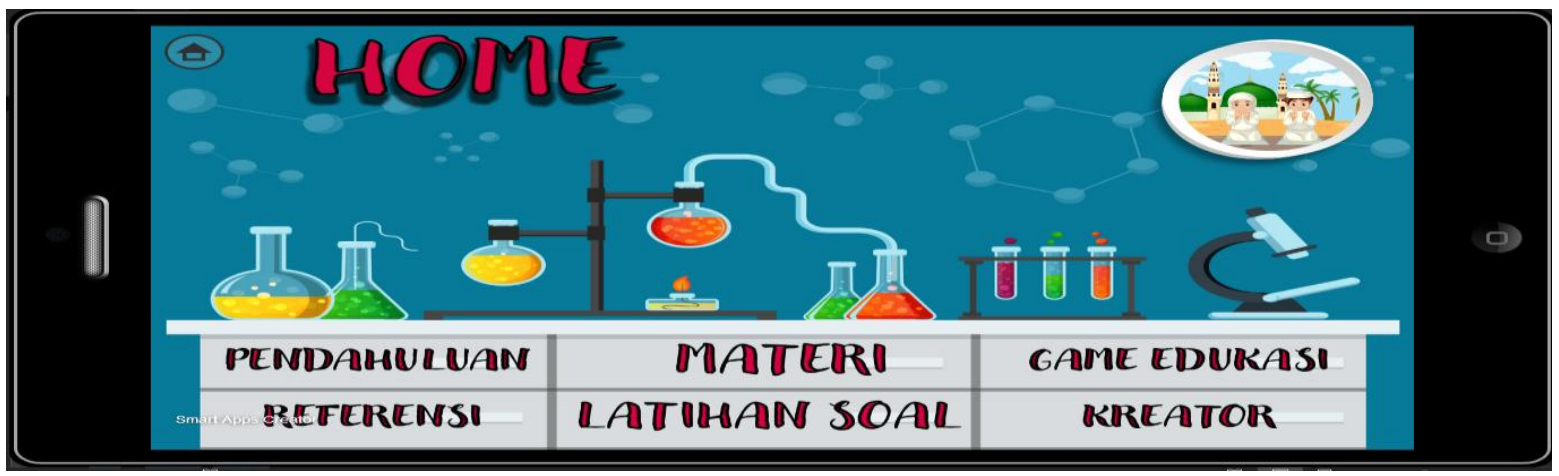

Figure 4. Homepage

b. Preliminary,

This introductory page is also equipped with various button features that will allow you to select the page you want to go. For example, if you want to enter the core competency page, click on the core competency on the introduction page in the upper right corner, to enter the basic competency page, click on the one that says competency. Based on the top right after the core competencies on the introduction page, the instructions apply the same to 
entering another page by clicking on the text that reads information on the introduction page, such as indicators of competency achievement and learning objectives

c. Material,

STREAM based water material. This page contains water material with aspects of STREAM. Science contains water pollution material, the role of water in life, water on earth is never exhausted. Technology contains Filtration and waterwheel. Religious contains verses of the Qur'an and hadiths related to water, including: (QS. Al Furqan: 48), (QS. Al Mursalat: 27), (QS. Al Maidah: 6), 4. (QS. As Sajdah: 27), (QS. Ar Ruum: 24). Engineering contains designing filtration technology and waterwheels which is provided in the form of videos on how to make waterwheels. Art aspects of art in every design. Mathematics contains material Calculating water discharge. It is enough to swipe on the button or the fingertip image to enter the material for each aspect.

\section{d. Educational Games,}

The practice questions page is also equipped with a button feature that will select the question page you want to go to, be it scientific literacy or water flow. If you want to enter one of the practice questions on the page, click on the text that you want to go to. For example, click on scientific literacy if you want to enter scientific literacy. The instructions apply the same to entering other pages by clicking on the text that reads a description on the educational game page, such as the water cycle and waterwheel, which you can see in Figure 5 .

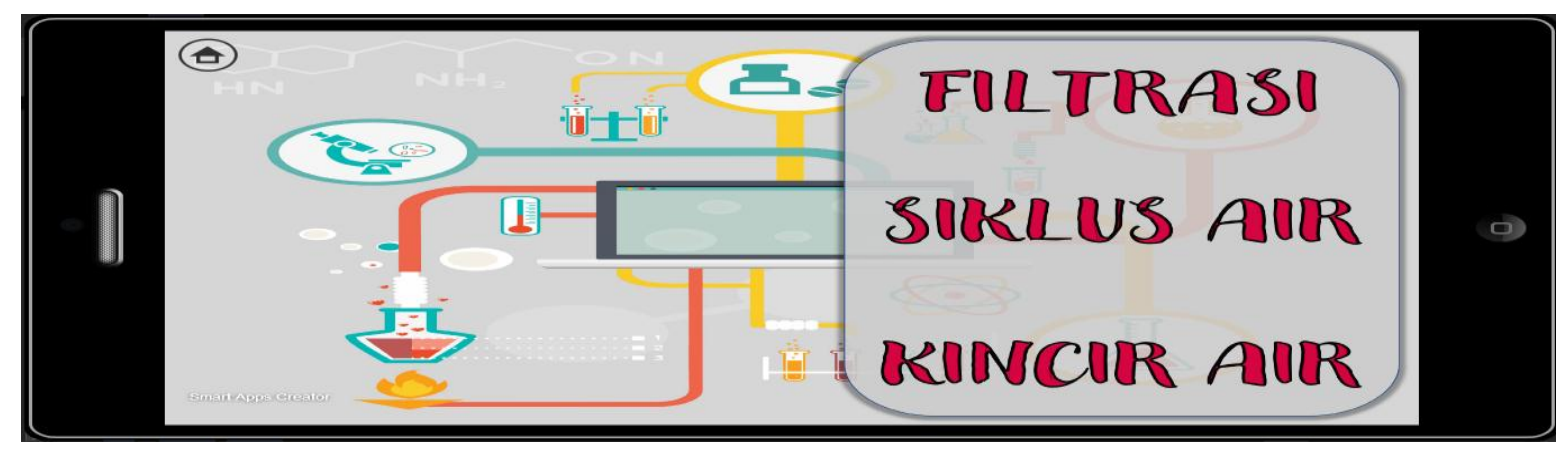

Figure 5. Educational Games

e. Exercises,

The practice questions page is also equipped with a button feature that will be able to select the question page that you want to go to, be it scientific literacy or water flow. If you want to enter on the page of one of the practice questions, click on the text that you want to go 
to. For example, if you want to enter scientific literacy, click on scientific literacy. The instructions apply the same to entering other pages by clicking on the text that reads the description on the practice questions page, which you can see in Figure 6.

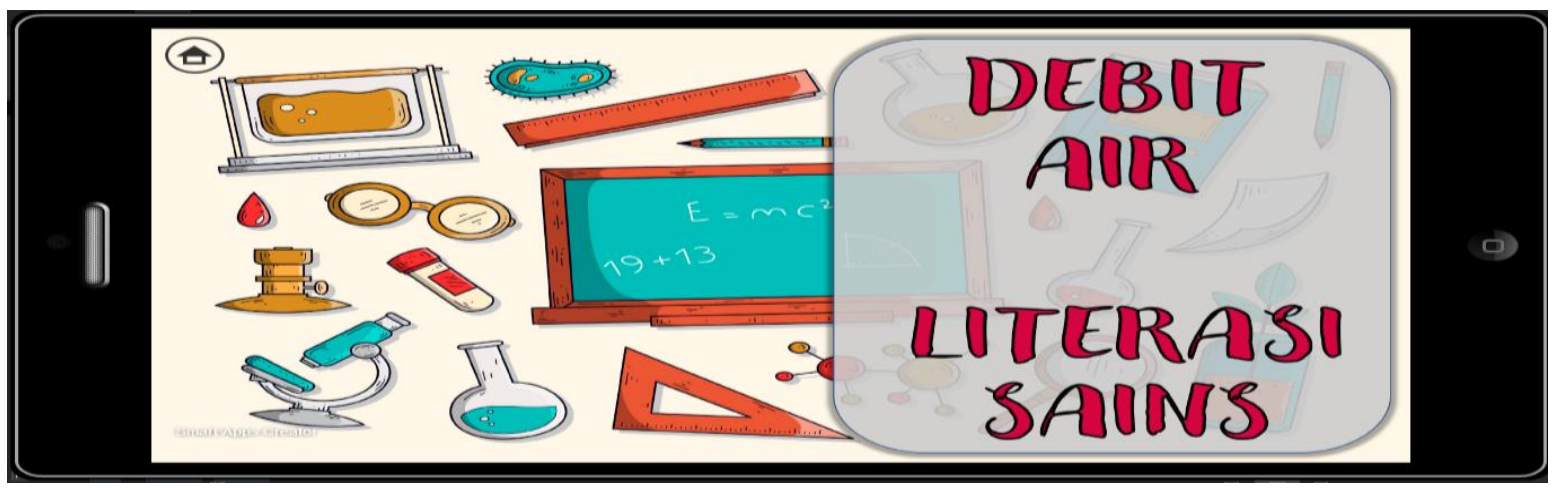

Figure 6. Practice Questions page

f. Creator or Developer (Developer),

Contains the identity of the developer or designer of the STREAM-based water material application. This page appears after clicking the box labeled creator on the menu page. The designer of the application, among others, Fenny Pebriani. The page can be seen in Figure 7.

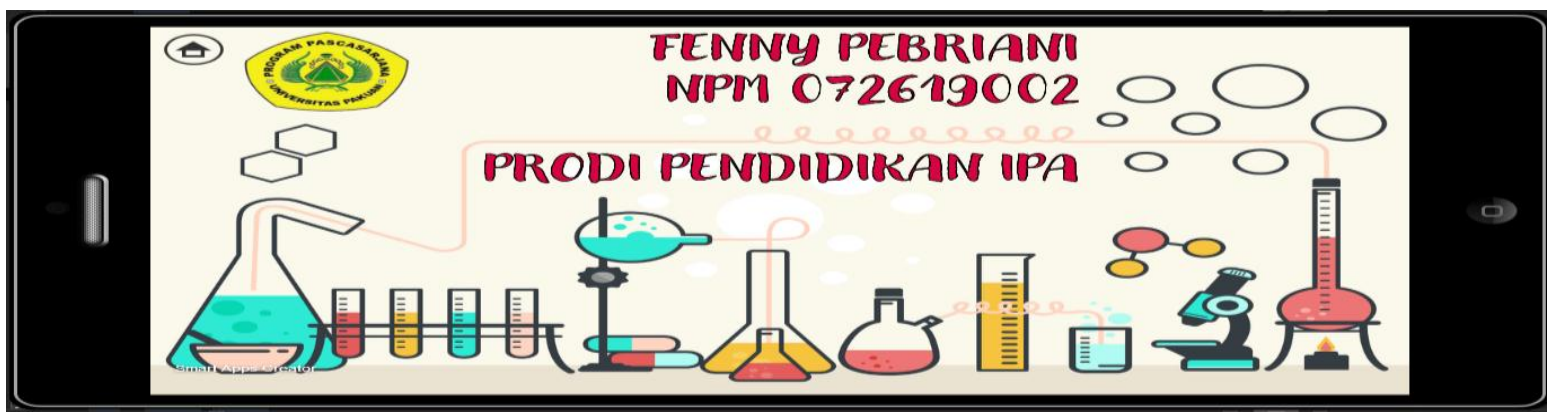

Figure 7. Creator's Page

g. Reference

Aspects of quality assessment include material (content), language and images, and presentation.

The results of the development of STREAM-based learning media for water materials indicate that it is necessary to create an organized science learning media. Before being made, a learning media development model must be designed by first collecting information in the field. It means gathering information on the needs of the learning media users. This is called the need analysis section, or referred to as the initial investigation phase (Rochmad, 2012). Several developers of learning media have also carried out this stage with various objects and technologies. The next stage is the design (design) is very important to be able to design in advance the media that will be made with the design of each display in the android slide. This 
stage requires the assets used to complement the media. Various elements of assets are required from images, text, videos, logos, colors, icons, sounds, etc. The teacher must look at the lesson plan or student worksheets (Layin Fauziyah, 2014). At this stage, storyboards are produced as an initial design for making media to focus and create learning media that are complete with various contents. The development stage is real action in making this SAC 3 learning media. The development of media that was originally only conventional became Android-based media. SAC 3 requires a careful understanding of design and application development techniques. When making this STREAM-based water material media, improving the design to manufacture often takes a long time. The repetition of making each slide to filling in the assets of video material, sound, and even the background has also been carried out to pursue the flexibility, convenience, and beauty of the media produced.

\section{CONCLUSION}

The developed STREAM-based teaching materials using Smart Apps Creator 3 have proven to be effective in improving students' scientific literacy. Using android in the science learning process during the current pandemic makes it easier for students to follow the process of teaching and learning activities wherever they are. The provision of interesting content in the SAC 3 application can streamline the process of learning activities so that students are not bored with the presentation of the material being taught. The increase in students' scientific literacy can be seen based on understanding after STREAM-based learning activities using SAC 3 by giving pretest and posttest questions.

\section{REFERENCES}

Aberilla, O. D., Salic, M. H., Orbita, R. R., Bagaloyos, J. B., Demayo, C. G., \& Torres, M. A. G. (2021). University Students' Acceptance of Evolution: Basis for STEM-based Instructional Design. International Journal of STEM Education for Sustainability, 1(1), 33-44. https://doi.org/10.53889/ijses.v1i1.3.

Abidin. (2014). Desain Sistem Pembelajaran dalam Konteks Kurikulum 2013. Refika Aditama: Bandung.

Afifah, R. N. (2018). Pengembangan Lembar Kerja Siswa (Lks) Ilmu Pengetahuan Alam Berbasis Metode Percobaan. Science Activities, 12(2), 2086 - 2096. http://repository.upy.ac.id/227/.

Agustina, T. W., Rustaman, N. Y., Riandi, \& Purwianingsih, W. (2019). Membekalkan Kreativitas Mahasiswa Melalui Strategi Pembelajaran Berbasis Stream Menggunakan Konten Bioteknologi Tradisional. Bioed UIN Jurnal Program Studi Pendidikan Biologi, 9(1).

Aprido B. Simamora, Wahono Widodo, \& I Gusti Made Sanjaya. (2020). Innovative Learning Model: Improving The Students' Scientific Literacy Of Junior High School. IJORER: International Journal of Recent Educational Research, 1(3), 271-285. https://doi.org/10.46245/ijorer.v1i3.55. 
International Journal of STEM Education for Sustainability, Vol 2, No.1, 2022, pp. 78-93

e-ISSN 2798-5091. DOI. 10.53889/ijses.v2i1.29

Arikunto, S. (2017). Pengembangan Instrumen Penelitian dan Penilaian Program. Yogyakarta: Pustaka Pelajar.

Ayuni, D., Marini, T., Fauziddin, M., \& Pahrul, Y. (2020). Kesiapan Guru TK Menghadapi Pembelajaran Daring Masa Pandemi Covid-19. Jurnal Obsesi: Jurnal Pendidikan Anak Usia Dini, 5(1), 414. https://doi.org/10.31004/obsesi.v5i1.579.

Aziz Hussin, A. (2018). Education 4.0 Made Simple: Ideas For Teaching. International Journal of Education and Literacy Studies,6(3), 92-98. https://doi.org/10.7575/aiac.ijels.v.6n.3p.92.

Azizah, W. A., Sarwi, S., \& Ellianawati, E. (2020). Implementation of Project -Based Learning Model (PjBL) Using STREAM-Based Approach in Elementary Schools. Journal of Primary Education, 9(3), 238-247. https://doi.org/10.15294/jpe.v9i3.39950.

Bahri, S. (2018). Pengembangan Kurikulum Berbasis Multikulturalisme di Indonesia (Landasan Filosofis dan Psikologis Pengembangan Kurikulum Berbasis Multikulturalisme). In Jurnal Ilmiah DIDAKTIKA (Vol. 19, Issue 1, pp. 69-88).

Bao, W. (2020). COVID - 19 and Online Teaching in Higher Education: A Case Study of Peking University. Human Behavior and Emerging Technologies, 2(2), 113-115. https://doi.org/10.1002/hbe2.191.

Dewi Kusumaningsih, Bety Ayu Windi Ariyanto, Haryanti Budi Utami, \& Krisna Adi Ismaya. (2019). La PUISIFY the Form of Application-Based Poetry Learning Media SAC.2.0 on Android. AKSIS: Jurnal Pendidikan Bahasa Dan Sastra Indonesia, 3(2), 334-336. https://doi.org/10.21009/aksis.030210.

Dewi, W. A. F. (2020). Dampak COVID-19 terhadap Implementasi Pembelajaran Daring di Sekolah Dasar. Edukatif: Jurnal Ilmu Pendidikan, 2(1), 55-61. https://doi.org/10.31004/edukatif.v2i1.89.

Dhawan, S. (2020). Online Learning: A Panacea in the Time of COVID-19 Crisis. Journal of Educational Technology Systems, 49(1), 5-22. https://doi.org/10.1177/0047239520934018.

El Islami, R. A. Z., Nahadi, N., \& Permanasari, A. (2016). Membangun Literasi Sains Siswa Pada Konsep Asam Basa Melalui Pembelajaran Inkuiri Terbimbing. Jurnal Penelitian Dan Pembelajaran IPA, 2(2), 110. https://doi.org/10.30870/jppi.v2i2.662.

English, L. D., \& King, D. T. (2015). STEM learning through engineering design: fourth-grade students, investigations in aerospace. International Journal of STEM Education. https://doi.org/10.1186/s40594-015-0027-7.

Farwati, R., Metafisika, K., Sari, I., Sitinjak, D. S., Solikha, D. F., \& Solfarina, S. (2021). STEM Education Implementation in Indonesia: A Scoping Review. International Journal of STEM Education for Sustainability, 1(1), 11-32. https://doi.org/10.53889/ijses.v1i1.2.

Fitriyani, Y., Fauzi, I., \& Sari, M. Z. (2020). Motivasi Belajar Mahasiswa pada Pembelajaran Daring Selama Pandemik Covid-19. Profesi Pendidikan Dasar, 7(1), 121-132. https://doi.org/10.23917/ppd.v7i1.10973.

Fraenkel, J. R. \& Helen H. Hyun. (2012). How to Design and Evaluate Research in Education.

George, D., \& Mallery, P. (2018). IBM SPSS Statistics 25 Step by Step. In IBM SPSS Statistics 25 Step by Step. https://doi.org/10.4324/9781351033909. 
International Journal of STEM Education for Sustainability, Vol 2, No.1, 2022, pp. 78-93

e-ISSN 2798-5091. DOI. 10.53889/ijses.v2i1.29

Hake, R. R. (1999). Analyzing Change/Gain Scores. Unpublished. [Online] URL: http://www. Physics. Indiana. Edu/ sdi/AnalyzingChange-Gain. Pdf.

H Mubarok, N S Safitri, A. S. A. (2020). The Novelty of Religion and Art : Should We Combine with STEM Education? Studies in Philosophy of Science and Education, 1(3), 97-103

Hodges, C., Moore, S., Lockee, B., Trust, T., \& Bond, A. (2020). Remote Teaching and Online Learning. Educause Review, 1-15. https://er.Educause.edu/Articles/2020/3/the-DifferenceBetween-Emergency-Remote-Teaching-and-.

Ithnina, T. S. and M. S. (2013). Science and Technology Leaders for a Sustainable Future. 49-56. https://doi.org/10.7551/mitpress/9418.003.0007.

Khasanah, K., Muhlas, M., \& Marwani, L. (2020). Development of E-Learning Smart Apps Creator (SAC) Learning Media for Selling Employees on Paid Tv. Akademika, 9(02), 129-143. https://doi.org/10.34005/akademika.v9i02.819.

Kotsopoulos, K. I., Chourdaki, P., Tsolis, D., Antoniadis, R., \& Pavlidis, G. (2019). An Authoring Platform for Developing Smart Apps which Elevate Cultural Heritage Experiences : A System Dynamics Approach in Gamification. Journal of Ambient Intelligence and Humanized Computing, 0123456789. https://doi.org/10.1007/s12652-019-01505-w.

Mahase, E. (2020). Covid-19: WHO Declares Pandemic because of "Alarming Levels" of Spread, Severity, and Inaction. BMJ (Clinical Research Ed.), 368(m1036), 1. https://doi.org/10.1136/bmj.m1036.

Nasir Mustafa. (2020). Impact of the 2019 - 20 Coronavirus Pandemic on Education. International Journal of Health Preferences Research, 1-36.

Odegaard, M., Haug, B., Mork, S., \& Sorvik, G. O. (2015). Budding Science and Literacy. A Classroom Video Study of the Challenges and Support in an Integrated Inquiry and Literacy Teaching Model. Procedia - Social and Behavioral Sciences, 167(1877), 274-278. https://doi.org/10.1016/j.sbspro.2014.12.674.

OECD. (2003). Literacy Skills for The World of To- morrow - Further results from PISA 2000. Chapter 1 : Programme fro International Student Assesment and non-OECD countries. Paris : OECD.

OECD. (2013). PISA 2012. Assessment and analytical framework: mathematics, reading, science, problem solving and financial literacy. OECD Publishing. http://dx.doi.org/10.1787/9789264190511-en.

OECD\&ADB. (2015). Education in Indonesia: Rising to the Challenge. Paris: OECD Publishin

OECD. (2016). PISA 2015 Results: What students know and can do - student performance in reading, mathematics and science (Volume I), dx.doi.org.

OECD. (2017). PISA For development assessment and analitical framework: Reading, mathematics and science. www.oecd.org/about/publishing/corrigenda.htm.

OECD. (2019). PISA 2018 Assessment and Analytical Framework. Paris: OECD Publishing.

Ok, Ü. (2016). The Ok-Religious Attitude Scale (Islam): Introducing an Instrument Originated in Turkish for International Use. Journal of Beliefs and Values, 37(1), 55-67. https://doi.org/10.1080/13617672.2016.1141529. 
International Journal of STEM Education for Sustainability, Vol 2, No.1, 2022, pp. 78-93

e-ISSN 2798-5091. DOI. 10.53889/ijses.v2i1.29

Polya, G. 1973, How To Solve It. New Jersey: Princeton University Press. Rodríguez, Jorge -Chueca, Agustín Molina-García, César García-Aranda, Javier Pérez \& Encarnación.

Rekhawi, H. A. Al, \& Abu-naser, S. S. (2018). Android Applications UI Development Intelligent Tutoring System. International Journal of Engineering and Information Systems (IJEAIS), 2(January), 1-14.

Roza, D., Nurhafizah, N., \& Yaswinda, Y. (2019). Urgensi Profesionalisme Guru Pendidikan Anak Usia Dini dalam Penyelenggaraan Perlindungan Anak. Jurnal Obsesi : Jurnal Pendidikan Anak Usia Dini, 4(1), 277. https://doi.org/10.31004/obsesi.v4i1.325.

Sadikin, A., \& Hamidah, A. (2020). Pembelajaran Daring di Tengah Wabah Covid-19. Biodik, 6(2), 109-119. https://doi.org/10.22437/bio.v6i2.9759.

Sahu, P. (2020). Closure of Universities Due to Coronavirus Disease 2019 (COVID-19): Impact on Education and Mental Health of Students and Academic Staff. Cureus, 2019(April). https://doi.org/10.7759/cureus.7541.

Thiagarajan, \& Sivasailam. (1974). Instructional Development for Training Teachers of Exceptional. Bloomington, Indiana USA: National Center for Improvement of Educational Systems.

Wang, H., Wang, Z., Dong, Y., Chang, R., Xu, C., Yu, X., Zhang, S., Tsamlag, L., Shang, M., Huang, J., Wang, Y., Xu, G., Shen, T., Zhang, X., \& Cai, Y. (2020). Phase-Adjusted Estimation of the Number of Coronavirus Disease 2019 Cases in Wuhan, China. Cell Discovery, 6(1), 4-11. https://doi.org/10.1038/s41421-020-0148-0.

World Health Organization. (2020). Key Messages and Actions for COVID-19 Prevention and Control in Schools (L. Bender (ed.); Issue March). UNICEF.

Zubaidi, M. (2020). Hubungan Profesionalisme Pendidik Pendidikan Anak Usia Dini dengan Efektivitas Pembelajaran PAUD di Kota Gorontalo. In Jurnal Obsesi : Jurnal Pendidikan Anak Usia Dini (Vol. 4, Issue 2, p. 1060). https://doi.org/10.31004/obsesi.v4i2.505. 